\title{
The Montessori Approach as a Model of Personalized Instruction
}

Maruša Mavrič, University of Maribor, Slovenia

Keywords: personalized learning, Montessori approach, models for personalization, strategies for personalization

\begin{abstract}
I present a brief overview of the key elements of personalized learning and Montessori education, a related pedagogical approach, aiming to examine common theoretical principles and key elements. I discuss the common features of personalized instruction and the Montessori approach of education. Both personalized instruction and the Montessori approach stand firmly on a constructivist paradigm and share many philosophical and theoretical principles. Research has shown that Montessori education is one of the most visible models that incorporates numerous aspects of personalized instruction and shares many common elements with personalized learning. This research has shown that, while personalized instruction also suggests many strategies for implementation of the concept, Montessori education actualizes the principles of personalized learning.
\end{abstract}

The shift from the industrial age to a knowledgebased information age caused a change in desired educational outcomes. The need for problem-solving, innovative, and collaborative individuals led to the emergence of a new discipline in education that links the terms individualized and personalized instruction, self-directed, active, student-centered, independent, and differentiated learning into a concept of tailored education. Although these terms tend to be too general and with broad implications, some of them are often used synonymously with each other or as a related term. With the aim of clarifying the correlation and to differentiate between their usages, I present the definitions of the frequently used and often overlapping terms from the field of tailored education in Table 1.

Although these terms are frequently used interchangeably because their aim is to achieve the same goal, it is important to update the definition of personalized learning and give a brief history to acknowledge its change over the last half century.

Personalized learning has roots in several learning theories, and it has been influenced by many learning strategies. As early as the 17 th and 18th centuries, educators like Comenius, Rousseau, Pestalozzi, and Froebel strived to portray knowledge as "dynamic (rather than changeless), education as personal growth, human nature as flexible, and learners as partners in the learning process" (Keefe \& Jenkins, 2000, p. 19). Dewey believed schools should be the foundation for democracy. His Laboratory School, founded in 1896, was an attempt to establish a creative environment and test educational theories (Mayhew \& Edwards, 1936). The curriculum was organized around occupations that "encourage students to begin what interested them and then to 
Table 1

Definitions of Frequently Used and Overlapping Terms From the Field of Tailored Education

\begin{tabular}{|c|c|c|}
\hline Term & Definition & Source \\
\hline \multirow[t]{2}{*}{$\begin{array}{l}\text { Individualized } \\
\text { learning }\end{array}$} & $\begin{array}{l}\text { Instruction in which "the child's characteristics, rather than } \\
\text { prescribed academic content, provide the basis for teaching } \\
\text { techniques" }\end{array}$ & $\begin{array}{l}\text { Hallahan et al. (2020, p. } \\
\text { 10) }\end{array}$ \\
\hline & $\begin{array}{l}\text { "To effectively individualize instruction, it is necessary to examine } \\
\text { the interactions between various learner characteristics and multiple } \\
\text { instructional and presentation strategies." }\end{array}$ & McManus (2000, p. 220) \\
\hline \multirow[t]{4}{*}{$\begin{array}{l}\text { Self-directed } \\
\text { learning }\end{array}$} & $\begin{array}{l}\text { "a process in which individuals take the initiative, with or without } \\
\text { the help of others in diagnosing their learning needs, formulating } \\
\text { learning goals, identifying human and material resources for } \\
\text { learning, choosing and implementing appropriate learning strategies, } \\
\text { and evaluating learning outcomes" }\end{array}$ & Knowles (1975, p. 18) \\
\hline & $\begin{array}{l}\text { "a form of study in which individuals have responsibility for } \\
\text { planning, implementing and evaluating their own work" }\end{array}$ & Iwasiw (1987, p. 222) \\
\hline & $\begin{array}{l}\text { "when students take the initiative for their own learning, diagnosing } \\
\text { needs, formulating goals, identifying resources, implementing } \\
\text { appropriate activities and evaluating outcomes" }\end{array}$ & $\begin{array}{l}\text { Spencer \& Jordan (1999, } \\
\text { p. 1281) }\end{array}$ \\
\hline & $\begin{array}{l}\text { "learning process in which the learner took the responsibility and } \\
\text { worked independently on his own in the process of learning" }\end{array}$ & $\begin{array}{l}\text { Williamson (2007), as } \\
\text { cited in Dehnad et al. } \\
(2014, \text { p. 5185) }\end{array}$ \\
\hline $\begin{array}{l}\text { Student-centered } \\
\text { learning }\end{array}$ & $\begin{array}{l}\text { "The concept of the student's choice in their education; others see } \\
\text { it as being about the student's choice in their education; others } \\
\text { see it as being about the student doing more than the lecturer } \\
\text { (active versus passive learning); while others have a much broader } \\
\text { definition which includes both of these concepts but, in addition, } \\
\text { describes the shift in the power relationship between the student } \\
\text { and the teacher." }\end{array}$ & $\begin{array}{l}\text { O’Neill \& McMahon } \\
(2005, \text { p. 29) }\end{array}$ \\
\hline \multirow[t]{2}{*}{ Active learning } & $\begin{array}{l}\text { "instructional activities involving students in doing things and } \\
\text { thinking about what they are doing" }\end{array}$ & $\begin{array}{l}\text { Bonwell \& Eison (1991, } \\
\text { p. 3) }\end{array}$ \\
\hline & $\begin{array}{l}\text { "any instructional method that engages students in the learning } \\
\text { process" }\end{array}$ & Prince (2004, p. 223) \\
\hline $\begin{array}{l}\text { Independent } \\
\text { learning }\end{array}$ & $\begin{array}{l}\text { "an educational system in which the learner is autonomous and } \\
\text { separated from his teacher by space and time so that communication } \\
\text { is by print, electronic or another non-human medium" }\end{array}$ & Moore (1973, p. 663) \\
\hline \multirow[t]{3}{*}{$\begin{array}{l}\text { Differentiated } \\
\text { learning }\end{array}$} & $\begin{array}{l}\text { "the process of matching learning targets, tasks, activities, resources, } \\
\text { and learning support to individual learners' needs, styles, and rates } \\
\text { of learning" }\end{array}$ & $\begin{array}{l}\text { Stradling \& Saunders } \\
(1993, \text { p. 129) }\end{array}$ \\
\hline & $\begin{array}{l}\text { "philosophy of teaching that is based on the premise that students } \\
\text { learn best when their teachers accommodate the differences in their } \\
\text { readiness levels, interests and learning profiles" }\end{array}$ & Tomlinson (2005, p. 263) \\
\hline & $\begin{array}{l}\text { "a pedagogical approach to teaching and learning for students of } \\
\text { differing readiness levels, interests, and modes of learning within the } \\
\text { same classroom" }\end{array}$ & $\begin{array}{l}\text { Landrum \& McDuffie, } \\
(2010, \text { p. 9) }\end{array}$ \\
\hline
\end{tabular}


progress to more formal academic topics linked to their interests" (Keefe \& Jenkins, 200, p. 20). Bloom's theory of mastery learning, promoted in the 1950s and 1960s as an instructional method that "advances students from one topic of study to the next based on their mastery of the current topic," emphasized the importance of students having some control over the pace of their learning (Murphy, 2016, p. ii).

Keller's (1968) Personalized System of Instruction was one of the first attempts to implement personalized instruction in a time-based and standardized system. He outlined the five key features of personalized learning: self-pacing, mastery of material before proceeding to the next material, use of lectures for motivational purposes, importance of the written word, and use of peer mentors.

The NASSP Model Schools Project (1969-1974) enhanced Keller's idea and promoted a change in the school environment-specifying new student and teacher roles, flexible schedules, nongraded assessment, and new learning materials and activities — and defined three modes of learning: group presentation, discussion, and independent study (Keefe \& Jenkins, 2000). Although the Model Schools were variously successful in making a difference in the learning of individual students, the project did not affect secondary education as expected in the 1970s and beyond "because of a 'back to basics' backlash at that time and subsequent waves of reform under such mottos as excellence and quality" (Keefe \& Jenkins, 2000, p. 24). Five of the most successful schools in the Model Schools Project formed a private nonprofit follow-up as a regional self-help network of schools and districts.

The Learning Environments Consortium International (LEC International), founded in 1974, aimed to assist schools in developing personalized education programs. Keefe's systematic model of personalization for LEC International provided more information about the model employed by the Model Schools Project and specified personalized learning as "a systematic effort on the part of a school to take into account individual student characteristics and effective instructional practices in organizing the learning environment." (Keefe, 2007, p. 219). In the mid-1970s, Carroll's new look at the relationship between general and special education led to the definition of three elements of a personalized approach: actively involved learner, teacher as a learning facilitator, and success-oriented students' program (Keefe, 2007).
The Coalition of Essential Schools was established in 1979 as a result of $A$ Study of High Schools (Sizer, 1984). By the mid-1990s, about 250 schools had moved beyond the formative stages and "were playing out their insights into student intellectual development, the meaning of essential knowledge and skills, personalization of teaching and learning, student-as-worker and teacher-as-coach, and demonstration of student mastery by exhibition" (Keefe \& Jenkins, 2000, p. 30). In the 1990s, Wang researched the Adaptive Learning Environments Model, "an educational approach that targeted instructional strategies to the needs of each student [that] was particularly responsive to diverse student populations in classrooms" (Murphy, 2016, p. ii), which later became a component of Community for Learning, one of the first comprehensive school reform models validated by the U.S. Department of Education. The projects Braining Ranks I and II (established in 1996 and 2004, respectively) induced American high schools to substantive renewal, guided by six main themes as 13 sets of recommendations, and resulted in an updated definition of personalization as

a learning process in which schools help students assess their own talents and aspirations, plan a pathway toward their own purposes, work cooperatively with others on challenging tasks, maintain a record of their explorations, and demonstrate their learning against clear standards in a wide variety of media, all with the close support of adult mentors and guides. (Keefe, 2007, p. 219)

In 2000, LEC International also updated its personalized education model, focusing specifically on the instructional component. Keefe and Jenkins (2000) defined six basic elements of personalized instruction of two components: cultural (i.e., dual teacher role, diagnosis of student-learning characteristics, school culture of collegiality) and contextual components (i.e., interactive learning environment, flexible scheduling and pacing, authentic assessment).

The Bill \& Melinda Gates Foundation (2005) incorporated personalized learning components into its vision for High Schools for the New Millennium (2005) and advocated rigor, relevance, and relationship. The U.S. Department of Education's National Educational Technology Plan (Office of Educational Technology, 
2010) clarified that personalization is "broader than individualization or differentiation, in that it affords the learner a degree of choice about what is learned, when it is learned, and how it is learned" (Murphy, 2016, p. ii). Later, the U.S. Department of Education funded the Center on Innovations in Learning, founded in 2012; among its charges was to assist state education agencies and districts with personalized learning (Redding, 2016).

Several authors have contributed a description or definition of personalized learning (Keefe \& Jenkins, 2000; Murphy et al., 2001). To present a broad view on personalized learning, I present a lean and serviceable definition: "Personalized learning is an instruction that is differentiated and paced to the needs of the learner and shaped by the learning preferences and interests of the learner" (Taylor \& Gebre, 2016, p. 205).

Although antecedents of personalization have been known under different names, including "non-graded education, continuous progress education, individualized instruction, individually guided or prescribed education" (Keefe \& Jenkins, 2000, p. 37), personalized learning is more systematic in organization, broader in scope, and more authentic in its goals and strategies compared to other related concepts, such as individualized instruction (Houchens et al., 2014).

\section{Theoretical Foundations of Personalized Learning and Montessori Approach}

Personalized learning is not itself a theory of learning but "an overarching method to leverage existing learning theories, in conjunction with educators' practical experience and learners' input, to modify aspects of a learning environment to meet learner needs" (Walkington \& Bernacki, 2020, p. 240). Personalized learning as a pedagogical philosophy emerged from "several theoretical frameworks and psychological constructs, including goal-orientation theory, self-determination theory, self-regulation, the theory of flow and constructivism" (Houchens et al., 2014, p. 5).

The constructivist paradigm, which shifts the focus from knowledge as a product to knowing as a process (Ültanir, 2012), is a large enough umbrella to accommodate both personalized instruction and Montessori pedagogy. While a variety of definitions of the term "constructivism" have been suggested, they all share the idea that the development of understanding requires an actively engaged learner in making meaning. In personalized learning, "constructivist teachers build instruction on student styles and skills, and encourage students to seek out personal knowledge of a topic" (Keefe \& Jenkins, 200, p. 56). Piaget's fundamental idea of constructivism is that the learner must construct knowledge, which applies to both personalized learning and Montessori education. In personalized instruction, "learning requires the active, constructive involvement of the learner" (Patrick et al., 2013, p. 6). Both Jean Piaget (1964) and Maria Montessori (1912/1964) shared the belief that the development of knowledge is a spontaneous and natural process, occurring through action that makes up logical structures that Piaget called operations and that Dr. Montessori believed happens through manipulation of an object (Gutek, 2004). Both authors contributed a developmental theory: Dr. Montessori provided a holistic view of the developing human being in her four planes of development (Grazzini, 1996), and Piaget focused on the four stages of cognitive development (Piaget, 1964). Both theories contradict the old idea of linear development and emphasize the idea of development as a transformation but also point out the interdependence of the planes or stages. In Dr. Montessori's theory, the sensitivities of each stage guide the development and determine its rhythm (Grazzini, 1996), but Piaget went further, describing four interrelated factors that can explain development from one stage to another: maturation, experience, social transmission, and equilibrium (Piaget, 1964). These stages match Dr. Montessori's ideas of interaction between nurture and nature, moving from concrete to abstract at the child's own pace, emphasizing the child's cognitive needs, repetitive behavior, self-direction, and the changed role of the teacher (Gutek, 2004). Despite many parallels, the authors did diverge in significant ways; for example, Dr. Montessori was committed to practice and Piaget to theory (Elkind, 1967).

One of the attributes of both personalized learning and Montessori education is social construction, which describes how students "build ideas through relationships with others as they theorize and investigate in pursuit of common learning goals" (Kallick \& Zmuda, 2017, p. 4). This idea is based on Vygotsky's (1980) social construction of knowledge that describes learning primarily as a social activity, and in which participation in the social life of the school is critical for learning to occur (Patrick et al., 2013, p. 7). Likewise, Lave and Wenger (1991) supported the idea in both Montessori education and personalized learning that learning is a 
social process in which knowledge is co-constructed by constant interactions. Dennen and Burner (2008) defined apprenticeship as a "process through which a more experienced person assists a less experienced one by way of demonstration, support and examples" (p. 426).

Vygotsky argued that "the presence of people in the same environment, and the cooperation with peers, induces a reflection and an auto-regulation of one's own behaviour" (De Marsico et al., 2011), which indicates that social learning precedes individual competencies and determines and prepares cognitive development. Vygotsky's (1980) idea of the zone of proximal development describes the "distance between the actual developmental level as determined by independent problem-solving and the level of potential development as determined through problem-solving under adult guidance or in collaboration with more capable peers" (Vygotsky, 1980 p. 86). Learners' goals have to be personalized and meaningful because activities that are within the individual's zone of proximal development will stimulate the greatest intrinsic motivation (Malone \& Lepper, 1987). Vygotsky's ideas also support Dr. Montessori's concept of normalization, which describes the occurrence of spontaneous discipline, continual and happy work, and social sentiments of help and sympathy for others (Montessori, 1949/1973). Both Vygotsky and Dr. Montessori emphasized the importance of the scientific approach in pedagogy and agree that instruction can drive the development of the children, but Vygotsky stressed the importance of co-construction and believed nothing that is biologically determined in a child cannot be shaped in a social environment (Bodrova, 2003).

Dewey accentuated the importance of the learner's own experiences, which supports both personalized instruction and Montessori education (Hickman \& Alexander, 1998). In Bruner's (1961) concept of discovery learning, "practice in discovering for oneself teaches one to acquire information in a way that makes that information more readily viable in problem solving" ( $\mathrm{p}$. 26). Furthermore, Bransford et al. (1990) introduced anchored instruction, a technology-enhanced learning approach to problem-solving in a goal-based scenario model. However, Collins et al. (1988) introduced the concept of cognitive apprenticeship, which emphasizes the purposeful practice of target skills within the functional context of their use (Lim-Dunham et al., 2016) and which, to a certain extent, can be linked to both personalized instruction and the Montessori approach.
Cognitive apprenticeship focuses on four dimensions of any learning environment: content, method, sequencing, and sociology. The methods associated with cognitive apprenticeship are modeling, coaching, scaffolding, articulation, reflection, and exploration (Collins et al., 1988). The concept suggests increasing complexity and diversity by focusing on conceptualizing the whole task before focusing on its parts. Situated learning describes instruction in which students work on realistic tasks in cooperative communities of practice driven by intrinsic motivation (Collins et al., 1988; Lave \& Wenger, 1991).

Bruner (1961) argued the importance of education supporting the development of a student as an autonomous and self-regulated individual. The goal of both Montessori education and personalized learning is to develop self-regulated learners who are able to make independent choices, direct and plan their own learning, and tailor the learning process according to their own needs, interests, and preferences.

Self-determination theory provides an understanding of motivation that "requires a consideration of innate psychological needs for competence, autonomy, and relatedness" (Deci \& Ryan, 2000, p. 227). It is defined as a "combination of skills, knowledge, and beliefs that enable a person to engage in goal-directed, selfregulated, autonomous behavior" (Field et al., 1998, p. 2). Casquejo Johnston (2016) argued that Montessori education includes practices and structures that support the intellectual, psychological, and emotional development of children and align with the basic needs defined in self-determination theory. Research indicates that personalized learning interventions with an applied self-determination theory framework enhance "students' learning needs and interests, allowing for more learning control and leading to students' increased interest in learning and understanding the course topics" (Alamri et al., 2020, p. 325).

Goal-orientation theory suggests how students should have their own goals for learning and argues how students' goals mediate the quality of their engagement at school. In Montessori education, goal-setting and -achieving practices are "designed to foster student feelings of control over their education and their ultimate sense of autonomy in place of working for the sake of pleasing a teacher or surpassing peers" (Murray, 2011, p. 6). By focusing on students' mastery goals, personalized instruction highlights students' own progression and development of a new skill (Watson \& Watson, 
2016). Both personalized learning and Montessori education have much in common with goal-orientation theory (Rathunde, 2003), which argues that students should have their own goals for learning. Kaplan and Maehr (2007) stated that the quality of engagement in tasks is higher when "mastery goals are perceived to be emphasized on an achievement context and when students endorse them as an orientation” (p. 170).

Both personalized learning and Montessori education are also linked to optimal experience theory and flow theory (Csikszentmihalyi \& Rathunde, 2014). Flow theory describes the moments when a person is fully connected to a task at hand, relatively oblivious to the passage of time, and clear about what needs to be done from one moment to the next (Rathunde, 2001, p. 14). Shernoff et al. (2003) found that students were more interested in challenging activities that required high skill, and they reported higher levels of concentration and enjoyment upon completing the task.

\section{Key Components of Personalized Instruction}

The literature on personalized instruction highlights several interpretations of key components of personalized instruction (Department for Education and Skills, 2004; Keefe \& Jenkins, 2000; Murphy et al., 2001). Together, these key elements constitute the culture and context of personalized instruction (Keefe, 2007). Because the emphasis is on a learning paradigm rather than on a teaching paradigm, the teacher's role shifts from teacher as lecturer to facilitator of the process of learning (Keefe \& Jenkins, 2000). As subject-matter coaches, consultants, and facilitators, teachers spend less time lecturing and more time demonstrating, giving feedback to students, preparing, and analyzing (Keefe \& Jenkins, 2000). Teachers assist learners in setting goals and designing or selecting tasks; they facilitate task performance and learning, help evaluate performance and learning, and mentor learners (Watson \& Reigeluth, 2008).

To personalize the learning process, it is crucial to properly diagnose relevant student-learning characteristics. Keefe and Jenkins (2000) proposed the diagnosis of student's developmental characteristics (physical development and maturation, psychological and sociological development), learning styles (cognitive, affective, physiological), and student-learning history. To achieve the desired outcomes, students and teachers have to work together to form a strong school culture of collegiality (Keefe \& Jenkins, 2002), which promotes interaction, dialogue, and thoughtful reflection.

The aim of personalized instruction is to create learning communities within a constructivist environment in which students can work together in small groups that encourage collaboration and socialization (Keefe \& Jenkins, 2002). Personalized instruction has to form an interactive learning environment with a small group or school size, thoughtful classrooms, active learning experiences, and authentic student achievement (Keefe \& Jenkins, 2002).

Flexible scheduling and pacing enable students to engage in meaningful learning activities, make choices in curriculum and instruction, and form an environment in which both teachers and students determine how time is used (Keefe \& Jenkins, 2002). Because the focus is on real performance and mastery of a field of knowledge, students are involved in an authentic assessment of the improvement of student learning. To fit the purpose of instruction, different methods and different types of assessment (e.g., naturalistic, performance, portfolio) can be used.

\section{Montessori Pedagogy}

The development of Dr. Montessori's Method was significantly influenced by educational pioneers like Quintilian, Comenius, Rousseau, Séguin, Itard, Pestalozzi, and Fröbel (Gutek, 2004). Her successful work with mentally handicapped children provoked her to study education as a general field until 1907, when she was asked to direct a preschool day-care center in the district of San Lorenzo in Rome (P. P. Lillard, 1972). Through observation and experimentation, she noticed that children show their natural interest in learning in a properly prepared environment, and she detected two significant aids to the child's development: sensitive periods and the absorbent mind. During these sensitive periods, a child develops special sensitivities and interests and becomes capable of effectively learning certain matters (Phillips, 1977); children at the absorbent-mind stage absorb sensory impressions and information from their environment (Gutek, 2004). The prepared environment consists of a structured and orderly environment that cultivates sensory sensitivity, independence, and self-assurance with a possibility of choice (Gutek, 2004). Self-correcting didactic materials that promote autoeducation and intrinsic motivation 
enable the teacher's role to change from a transmitter of knowledge to a guide or mentor and diagnostician of a child's educational profile (Gutek, 2004). The Montessori Method allows children to move through the curriculum at their own pace in an encouraging atmosphere.

\section{Implemented Principles of Personalized Learning in the Montessori Approach}

To highlight the common elements of personalized instruction and the Montessori approach, it is important to describe the different stages of development in the Montessori approach and the adaptation of the instructional methods to different developmental stages of students; for example, the teacher has a different role when working with preschool children than with elementary students and adolescents. To indicate the shared elements of personalized instruction and the Montessori approach, universal principles of the Montessori approach that apply to all stages of student development are described.

Scholars do not agree on the foundational components of personalized learning, with some "focusing first on student-centered pedagogy and others focused on technocentric solutions" (Lokey-Vega \& Stephens, 2019, p. 312). Watson and Watson (2016) saw Montessori education as personalized because of the incorporation of student choice, student self-regulation, mastery-learning philosophy, portfolio assessments, and teacher-as-guide approach, despite Montessori schools' strictly limiting technology use (MacDonald, 2016). Keefe and Jenkins (2000) saw Montessori education as one of the strategies for personalizing instruction in which "students learn and apply many unique techniques to construct and apply knowledge and skills" (p. 108).

\section{A Dual Teacher Role}

When describing different strategies and tactics for personalizing instruction, Keefe and Jenkins (2000) argued that the Montessori teacher has a dual role, as a facilitator of knowledge who provides advice and as an instructional specialist. In the literature regarding the Montessori approach, the teacher is often referred to as a "directress" who brings the student into contact with appropriate elements of the school environment (Fleege, 1967). The Montessori teacher's role is to observe students, prepare the environment to best serve their developmental needs and interests, and guide them through the process of autoeducation and construction of their own knowledge (Montessori, 1912/1964).

Now the adult himself is part of the child's environment; the adult must adjust himself to the child's needs if he is not to be a hindrance to the child and if he is not to substitute himself for the child in the activities essential to growth and development. (Montessori, 1936/2013, p. 106)

In both personalized instruction and the Montessori approach, the teacher offers demonstration, instruction, and feedback. Both approaches emphasize independence and autoeducation to some extent. Montessori education places far more emphasis on autoeducation, however, while personalized learning endeavors to find the most suitable way for the development and learning of each individual learner, which can differ from one student to another.

\section{The Diagnosis of Relevant Student-Learning Characteristics}

Dr. Montessori developed her Method through clinical observation of children, in other words, through diagnosis of a student's learning characteristics (Gutek, 2004), which is one of six basic elements of personalized instruction, as suggested by Keefe and Jenkins (2000). The goal of both personalized instruction and Montessori education is to build a learning environment that best suits the needs, developmental stage, and interests of each student (Keefe \& Jenkins, 2002; P. P. Lillard, 1972). Montessori education goes further than personalized learning, though, emphasizing the importance of observation connected not only to students' learning but also to their behavior, well-being, and everything related to their development as a person (P. P. Lillard, 1972). Although Dr. Montessori acknowledged the importance of a comprehensive diagnosis of the student's learning (developmental level, learning traits, physical, psychological and sociological development), she collected most of the information through observation, not through surveys, inventories, or tests (Montessori, 1912/1964). On the other hand, personalized learning emphasizes the importance of different manners of diagnosing the relevant student-learning characteristics (Keefe \& Jenkins, 2000). Dr. Montessori's approach to the observation of students is holistic and does not 
include determining student-learning profiles; rather, it aims to help every individual student develop in the best way possible (P. P. Lillard, 1972). In contrast with personalized learning that focuses mainly on the academic perspective, Montessori education aims to develop students' democratic sensibilities within classroom activities as well (Williams \& Keith, 2000): "Montessori [education] teaches processes for developing and maintaining a sense of integrity, belonging, and general and personal well-being by actively involving children in creating the processes together." (Williams \& Keith, 2000, p. 219).

\section{A Culture of Collegiality in the School: A Constructivist Environment and Collaborative Learning Environments}

In both Montessori education and personalized instruction, teachers and students work together to develop a constructivist environment best suited to the needs and characteristics of students (Keefe \& Jenkins, 2002; P. P. Lillard, 1972). Students are free to make choices in their learning process in an environment that promotes interaction, dialogue, learning by doing, and thoughtful reflection (Keefe \& Jenkins, 2002; Montessori, 1912/1964). With all students able to freely choose their work, students are driven by intrinsic motivation (Keefe \& Jenkins, 2002; P. P. Lillard, 1972). In both approaches, classroom layout not only suits the physical characteristics of students, but also fosters collaborative learning communities and at the same time enables individual work (Gutek, 2004; Watson \& Watson, 2016). Keefe and Jenkins (2002) stated that collaborative learning arrangements in personalized instruction "provide an opportunity for students and teachers to work together to talk about their ideas and to sharpen their thinking” (p. 444). Collaborative learning arrangements are necessary for both personalized learning and Montessori environments because they promote interaction, dialogue, and thoughtful reflection (Keefe \& Jenkins, 2002).

\section{An Interactive Learning Environment}

To create the best possible learning environment for students, both approaches emphasize the importance of an interactive environment, with thoughtful learning activities that prepare students for real life (Keefe \& Jenkins, 2000; Montessori, 2007): "Education should not limit itself to seeking new methods for a mostly arid transmission of knowledge: its aim must be to give the necessary aid to human development." (Montessori, 2007, p. 84) In Montessori education, great emphasis is placed on students' development and learning through their environment using ready-made didactic materials (Gutek, 2004). Montessori teachers prepare the classroom environment, focusing on the common developmental characteristic of the whole group of students, while also considering the possible individual needs of every student. In personalized learning, far more emphasis is placed upon personalizing the whole process of learning to suit the learner's needs, including selecting the most appropriate environment for each individual student.

Personalized learning argues that small group or class size can "better support thoughtful conversation, learning by doing, apprenticeship experiences, and authentic student achievement" (Keefe \& Jenkins, 2000, p. 63), which aligns with Montessori classrooms that "employ an open concept in which desks are arranged in 'rafts' to promote individual and small-group learning and are composed of students across a three-year age range" (Lopata et al., 2005, p. 6). Darling-Hammond (1997) reported that

small schools (with enrollments of roughly 300 to 600) promote higher student achievement, higher attendance, lower dropout rates, greater participation in school activities, more positive feelings toward self and school, more positive behavior, less violence and vandalism and greater postschool success. (p. 136)

Montessori education allows far more flexibility in timing and age range (e.g., heterogeneous groups, uninterrupted work time) compared with personalized learning, which is, in the majority of instances, still implemented during traditional timetables and age-based classrooms. Multiage groups in Montessori schools enable that, "as children move through the classroom they are exposed to older and younger peers, facilitating both imitative learning and peer tutoring" (A. S. Lillard, 2016, p. 228).

\section{Active Learning Activities}

Personalized learning "encourages curriculum that supports purposeful learning which is similar to Montessori education's focus on student-developed plans of study and project-based learning" (Casquejo 
Johnston, 2019, p. 5). Keefe and Jenkins (2002) argued that teachers who are concerned about personalizing the learning process "believe in teaching through genuine experiences and thoughtful reflection" (p. 446). Both personalized learning and the Montessori approach give equal importance to active learning; Montessori education focuses more on "active sensorimotoric activities (feeling, touching, etc.) ... especially in the kindergarten-age" (van Hout-Wolters et al., 2000, p. 23), and personalized learning focuses on providing real-life learning richness and context in all learning situations (Keefe \& Jenkins, 2002).

\section{Flexible Scheduling and Pacing}

Flexible and adequate scheduling enables students to focus on performance rather than time and lets them engage in meaningful learning activities (Keefe \& Jenkins, 2000). Montessori education supports these activities and stresses the importance of uninterrupted cycles of work:

The mind takes some time to develop interest, to be set in motion, to get warmed up into a subject, to attain a state of profitable work. If at this time there is an interruption, not only is a period of profitable work lost, but the interruption, produces an unpleasant sensation which is identical to fatigue. (Montessori, 1989, p. 135)

The degree of flexibility of a school that incorporates personalized learning depends on the educational philosophy of the school: "If the philosophy is traditional, the schedule is likely to be very structured, even rigid. If the philosophy is constructivist or learner-centered, the schedule will almost necessarily be personalized or at least very flexible" (Keefe \& Jenkins, 2002, pp. 446-447).

\section{Assessment}

Dr. Montessori argued that children follow a law of maximum effort (i.e., they devote themselves wholly to mastering a task) and are in an environment to improve themselves for the sake of a process, not to achieve an end result (P. P. Lillard, 1972). Rather than assessing student competencies, Montessori teachers observe children's work (A. S. Lillard, 2016). Because most lessons are given individually or in small groups, teachers can delve into a student's level of understanding (Roemer, 1999). With older students (i.e., Secondary school and above), Montessori teachers use traditional assessment practices less frequently than traditional learning arrangements, preferring a combination of alternative assessment policies, such as portfolios and anecdotal and nongraded reports (Roemer, 1999). Although personalized learning stresses that the primary purpose of assessment should be the improvement of student learning, not sorting or grading (Keefe \& Jenkins, 2002), far more emphasis is placed on assessment itself. While Montessori teachers generally have negative attitudes toward testing (Haines, 1995), personalized instruction stresses that testing is just one form of assessment. Assessment "goes beyond testing and includes such activities as demonstrations, oral and written presentations, performances, contests, projects, and problem-solving activities" (Keefe \& Jenkins, 2002, p. 447), and the method of assessment should always fit the purpose of instruction. In general, Montessori education "downplays the role of high-stakes assessment” (Block, 2015, p. 45), favoring observational assessments to help students develop individual work plans and goals. Compared to Montessori education, some implementations of personalized learning place far more significance on assessments, as well as on agency and student ownership of learning, both of which support independence.

\section{Conclusions}

In this paper I have discussed the common features of personalized instruction and the Montessori approach of education. Both personalized instruction and the Montessori approach stand firmly on a constructivist paradigm and share many philosophical and theoretical principles. Research indicates that students attending Montessori schools achieve better academic outcomes compared to other public or charter elementary school education programs (Lillard \& Else-Quest, 2006), particularly in mathematics and science (Dohrmann, 2003). A Montessori environment also serves as a better base for the development of executive functions than do traditional arrangements (Diamond \& Lee, 2011).

Montessori education is one of the most visible and widespread models to incorporate numerous aspects of personalized instruction (Watson \& Reigeluth, 2008), including fostering intrinsic motivation, focusing on students, and actively involving students. My research has shown this, although personalized instruction suggests many strategies for implementation and differs from the Montessori approach in several ways, as described 
previously. Montessori education stands firmly as an actualization of the many principles of personalized learning.

Further research could examine which principles of personalized instruction are not well incorporated in the Montessori model and explore how to implement some of the key principles and strategies of personalized learning in a Montessori approach, especially for older students (i.e., adolescents).

\section{Author Information}

Maruša Mavrič is a doctoral student at the University of Maribor, Slovenia. She can be reached at marusa.mavric1@student.um.si

\section{References}

Alamri, H., Lowell, V., Watson, W., \& Watson, S. L. (2020). Using personalized learning as an instructional approach to motivate learners in online higher education: Learner self-determination and intrinsic motivation. Journal of Research on Technology in Education, 52(3), 322-352. https://doi.org/10.1080/15391523.2020.1728449

Bill \& Melinda Gates Foundation. (2005). High schools for the new millennium: Imagine the possibilities. https://docs.gatesfoundation.org/Documents/ EdWhitePaper.pdf

Block, C. R. (2015). Examining a public Montessori school's response to the pressures of high-stakes accountability. Journal of Montessori Research, 1(1), 42-54. https://doi.org/10.17161/jomr.v1i1.4913

Bodrova, E. (2003). Vygotsky and Montessori: One dream, two visions. Montessori Life, 15(1), 30-32. Research Gate. https://www.researchgate.net/ profile/Elena_Bodrova/publication/234745030 Vygotsky and Montessori_One Dream Two Visions/links/552c0fd60cf29b22c9c3ffdd.pdf

Bonwell, C. C., \& Eison, J. A. (1991). Active learning: Creating excitement in the classroom (ED336049). ERIC. https://files.eric.ed.gov/fulltext/ED336049.pdf

Bransford, J. D., Sherwood, R. D., Hasselbring, T. S., Kinzer, C. K., \& Williams, S. M. (1990). Anchored instruction: Why we need it and how technology can help. In D. Nix \& R. J. Spiro (Eds.), Cognition, education, and multimedia: Exploring ideas in high technology (pp. 115-141). Lawrence Erlbaum Associates, Inc.

Bruner, J. S. (1961). The act of discovery. Harvard Educational Review, 31, 21-32.

Casquejo Johnston, L. M. (2016). Examining Montessori middle school through a self-determination theory lens: A study of the lived experiences of adolescents. Journal of Montessori Research, 2(1), 27-42. https://doi.org/10.17161/jomr.v2i1.4994

Casquejo Johnston, L. M. (2019). Montessori middle school: The Erdkinder. Middle Grades Review, 5(3), Article 4. https://scholarworks.uvm.edu/mgreview/vol5/iss3/4

Collins, A., Brown, J. S., \& Newman, S. E. (1988). Cognitive apprenticeship: Teaching the craft of reading, writing and mathematics. Thinking: The Journal of Philosophy for Children, 8(1), 2-10. https://doi.org/10.5840/thinking19888129

Csikszentmihalyi, M., \& Rathunde, K. (2014). The development of the person: An experiential perspective on the ontogenesis of psychological complexity. In M. Csikszentmihalyi (Ed.), Applications of flow in human development and education: The collected works of Mihaly Csikszentmihalyi (pp. 7-79). Springer.

Darling-Hammond, L. (1997). The right to learn: A blueprint for creating schools that work. Jossey-Bass.

Deci, E. L., \& Ryan, R. M. (2000). The "what" and "why" of goal pursuits: Human needs and the selfdetermination of behavior. Psychological Inquiry, 11(4), 227-268. https://doi.org/10.1207/S15327965PLI1104 01

Dehnad, A., Afsharian, F., Hosseini, F., Arabshahi, S. K. S., \& Bigdeli, S. (2014). Pursuing a definition of self-directed learning in literature from 2000-2012. Procedia-Social and Behavioral Sciences, 116, 5184-5187. https://doi.org/10.1016/j.sbspro.2014.01.1097

De Marsico, M., Sterbini, A., \& Temperini, M. (2011). The zone of proximal development between adaptive learning and reputation-based group activities. Proceedings of the 17th International Conference on Distributed Multimedia Systems, Florence, Italy. https://pdfs.semanticscholar. org/2cb0/ 54f1a08982ef70c0594ec5fdb4200daa505c.pdf

Dennen, V. P., \& Burner, K. J. (2008). The cognitive apprenticeship model in educational practice. In J. M. 
Spector, M. D. Merrill, J. van Merriënboer, \& M. P. Driscoll (Eds.), Handbook of research on educational communications and technology (pp. 425-439).

Routledge.

Department for Education and Skills. (2004). A national conversation about personalised learning. Department for Children, Schools and Families and the Department for Innovation, Universities and Skills. https://dera.ioe.ac.uk/5932/1/personalisedlearning. pdf

Diamond, A., \& Lee, K. (2011). Interventions shown to aid executive function development in children 4 to 12 years old. Science, 333(6045), 959-964. https://doi.org/10.1126/science.1204529

Dohrmann, K. R. (2003). Outcomes for students in a Montessori program: A longitudinal study of the experience in the Milwaukee Public Schools. Association Montessori Internationale / USA. https://www.public-montessori.org/wp-content/ uploads/2016/10/Outcomes Milwaukee\%20b.pdf

Elkind, D. (1967). Piaget and Montessori. Harvard Educational Review, 37(4), 535-545. https://doi. org/10.17763/haer.37.4.n60v725054564376

Field, S., Martin, J., Miller, R., Ward, M., \& Wehmeyer, M. (1998). A practical guide to teaching self-determination. Council for Exceptional Children.

Fleege, U. H. (1967). Montessori pre-school education: Final report (ED017320). ERIC; De Paul University. https://files.eric.ed.gov/fulltext/ED017320.pdf

Grazzini, C. (1996). The four planes of development. NAMTA Journal, 21(2), 27-61. http:// keysoftheuniverse.com/4planesofdevelopment.pdf

Gutek, G. L. (2004). The Montessori Method: The origins of an educational innovation: Including an abridged and annotated edition of Maria Montessori's The Montessori Method. Rowman \& Littlefield.

Haines, A. M. (1995). Montessori and assessment: Some issues of assessment and curriculum reform. NAMTA Journal, 20(2), 116-130.

Hallahan, D. P., Pullen, P. C., Kauffman, J. M., \& Badar, J. (2020). Exceptional learners. In G. W. Noblit (Ed.), Oxford research encyclopedia of education. https://doi. org/10.1093/acrefore/9780190264093.013.926

Hickman, L. A., \& Alexander, T. M. (1998). The essential Dewey: Pragmatism, education, democracy (Vol. 1). Indiana University Press.

Houchens, G. W., Crossbourne, T.-A., Zhang, J., Norman, A. D., Chon, K., Fisher, L., \& Schraeder, M. (2014,
November 5-7). Personalized learning: A theoretical review and implications for assessing kid-FRIENDLy student outcomes. Paper presented at the annual meeting of the Mid-South Educational Research Association, Knoxville, TN, United States. https:// www.wku.edu/rocksolid/documents/personalized learning_a theoretical_review_and implications for_assessing_kidfriendly_student_outcomes houchens et al 2014.pdf

Iwasiw, C. L. (1987). The role of the teacher in selfdirected learning. Nurse Education Today, 7(5), 222-227. https://doi.org/10.1016/0260-6917(87)90005-0

Kallick, B., \& Zmuda, A. (2017). Students at the center: Personalized learning with habits of mind. ASCD.

Kaplan, A., \& Maehr, M. L. (2007). The contributions and prospects of goal orientation theory. Educational Psychology Review, 19(2), 141-184. https://doi.org/10.1007/s10648-006-9012-5

Keefe, J. W. (2007). What is personalization? Phi Delta Kappan, 89(3), 217-223. https://doi.org/10.1177/003172170708900312

Keefe, J. W., \& Jenkins, J. M. (2000). Personalized instruction: Changing classroom practice. Eye on Education.

Keefe, J. W., \& Jenkins, J. M. (2002). A special section on personalized instruction. Phi Delta Kappan, 83(6), 440-448. https://doi.org/10.1177/003172170208300609

Keller, F. S. (1968). “Good-bye, teacher...” Journal of Applied Behavior Analysis, 1(1), 79-89. https://doi.org/10.1901/jaba.1968.1-79

Knowles, M. S. (1975). Self-directed learning: A guide for learners and teachers. Cambridge Adult Education.

Landrum, T. J., \& McDuffie, K. A. (2010). Learning styles in the age of differentiated instruction. Exceptionality, 18(1), 6-17. https://doi.org/10.1080/09362830903462441

Lave, J., \& Wenger, E. (1991). Situated learning: Legitimate peripheral participation. Cambridge University Press

Lillard, A., \& Else-Quest, N. (2006). The early years: Evaluating Montessori education. Science, 313(5795), 1893-1894. https://doi.org/10.1126/science.1132362

Lillard, A. S. (2016). Montessori: The science behind the genius. Oxford University Press

Lillard, P. P. (1988). Montessori: A modern approach. Schocken Books. 
Lim-Dunham, J. E., Ensminger, D. C., McNulty, J. A., Hoyt, A. E., \& Chandrasekhar, A. J. (2016). A vertically integrated online radiology curriculum developed as a cognitive apprenticeship: Impact on student performance and learning. Academic Radiology, 23(2), 252-261. https://doi.org/10.1016/j.acra.2015.09.018

Lokey-Vega, A., \& Stephens, S. (2019). A batch of one: A theoretical framework for the personalized learning movement. Journal of Online Learning Research, 5(3), 311-330. http://editlib.org/p/210639

Lopata, C., Wallace, N. V., \& Finn, K. V. (2005). Comparison of academic achievement between Montessori and traditional education programs. Journal of Research in Childhood Education, 20(1), 5-13. https://doi.org/10.1080/02568540509594546

MacDonald, G. (2016). Technology in the Montessori classroom: Benefits, hazards and preparation for life (EJ1112230). ERIC. NAMTA Journal, 41(2), 99107. https://files.eric.ed.gov/fulltext/EJ1112230.pdf

Malone, T. W., \& Lepper, M. R. (1987). Making learning fun: A taxonomy of intrinsic motivations for learning. In R. E. Snow \& M. J. Farr (Eds.), Aptitude, learning, and instruction: Cognitive and affective process analyses (Vol. 3, pp. 223-253). Erlbaum.

Mayhew, K. C., \& Edwards, A. C. (1936). The Dewey School: The laboratory of the University of Chicago, 1896-1903. D. Appleton-Century.

McManus, T. F. (2000). Individualizing instruction in a web-based hypermedia learning environment: Nonlinearity, advance organizers, and self-regulated learners. Journal of Interactive Learning Research, 11(2), 219-251.

https://www.learntechlib.org/primary/p/8486/

Montessori, M. (1964). The Montessori Method (A. E. George, Trans.). Schocken Books. (Original work published 1912)

Montessori, M. (1973). The absorbent mind (C. A. Claremont, Trans.). Holt, Rinehart and Winston. (Original work published 1949)

Montessori, M. (1989). What you should know about your child. Clio.

Montessori, M. (2007). From childhood to adolescence (H. R. Lane, Trans.). Montessori-Pierson.

Montessori, M. (2013). The secret of childhood. Aakar Books. (Original work published 1936)

Moore, M. G. (1973). Toward a theory of independent learning and teaching. The Journal of Higher
Education, 44(9), 661-679.

https://doi.org/10.1080/00221546.1973.11776906

Murphy, J., Beck, L. G., Crawford, M., Hodges, A., \& McGaughy, C. L. (2001). The productive high school: Creating personalized academic communities. Corwin Press.

Murphy, M. (2016). Foreword. In M. Murphy, S. Redding, \& J. S. Twyman (Eds.), Handbook on personalized learning for states, districts, and schools (pp. i-vi). Center on Innovations for Learning, Information Age Publishing.

Murray, A. (2011). Montessori elementary philosophy reflects current motivation theories. Montessori Life, 23(1), 22-33.

Office of Educational Technology. (2010). Transforming American education: Learning powered by technology: National Education Technology Plan 2010. U.S. Department of Education. https://www.ed.gov/sites/default/files/netp2010.pdf

O’Neill, G., \& McMahon, T. (2005). Student-centred learning: What does it mean for students and lecturers? In G. O’Neill, S. Moore, \& B. McMullin (Eds.), Emerging issues in the practice of university learning and teaching (pp. 27-36). All Ireland Society for Higher Education (AISHE). http://eprints.teachingandlearning.ie/2917/1/ McCarthy\%20and\%20Higgs\%202005.pdf

Patrick, S., Kennedy, K., \& Powell, A. (2013). Mean what you say: Defining and integrating personalized, blended and competency education. International Association for K-12 Online Learning. https://aurora-institute. org/wp-content/uploads/mean-what-you-say-1.pdf

Phillips, S. (1977). Maria Montessori and contemporary cognitive psychology. British Journal of Teacher Education, 3(1), 55-68. https://doi.org/10.1080/0260747770030106

Piaget, J. (1964). Part I: Cognitive development in children: Piaget: Development and learning. Journal of Research in Science Teaching, 2(3), 176-186. https://doi.org/10.1002/tea.3660020306

Prince, M. (2004). Does active learning work? A review of the research. Journal of Engineering Education, 93(3), 223-231. https://doi.org/10.1002/j.2168-9830.2004.tb00809.x

Rathunde, K. (2001). Montessori education and optimal experience: A framework for new research. NAMTA Journal, 26(1), 11-43. 
Rathunde, K. (2003). A comparison of Montessori and traditional middle schools: Motivation, quality of experience, and social context. NAMTA Journal, 28(3), 13-52. https://www.public-montessori. org/wp-content/uploads/2016/10/Rathunde Comparison\%20of\%20Montessori\%20and\%20 Traditional\%20MiddleSchools-small.pdf

Redding, S. (2016). Competencies and personalized learning. In M. Murphy, S. Redding, \& J. S. Twyman (Eds.), Handbook on personalized learning for states, districts, and schools (pp. 3-18). Center on Innovations for Learning, Information Age Publishing.

Roemer, K. L. (1999). Assessment practices used by Montessori teachers of kindergarten through sixth grade students in the United States [Doctoral dissertation, University of Memphis].

Shernoff, D. J., Csikszentmihalyi, M., Shneider, B., \& Shernoff, E. S. (2003). Student engagement in high school classrooms from the perspective of flow theory. School Psychology Quarterly, 18(2), 158-176. https://doi.org/10.1521/scpq.18.2.158.21860

Sizer, T. R., \& National Association of Secondary School Principals. (1984). A study of high schools: A report of "Horace's compromise." National Association of Secondary School Principals.

Spencer, J. A., \& Jordan, K. R. (1999). Learner centred approaches in medical education. British Medical Journal, 318, 1280-1283. https://doi.org/10.1136/bmj.318.7193.1280

Stradling, B., \& Saunders, L. (1993). Differentiation in practice: Responding to the needs of all pupils. Educational Research, 35(2), 127-137. https://doi.org/10.1080/0013188930350202

Taylor, R. D., \& Gebre, A. (2016). Teacher-student relationships and personalized learning: Implications of person and contextual variables. In M. Murphy, S. Redding, \& J. S. Twyman (Eds.), Handbook on personalized learning for states, districts, and schools (pp. 205-220). Center on Innovations for Learning, Information Age Publishing.

Tomlinson, C. A. (2005). Grading and differentiation: Paradox or good practice? Theory Into Practice, 44(3), 262-269. https://doi.org/10.1207/s15430421tip4403_11

Ültanir, E. (2012). An epistemological glance at the constructivist approach: Constructivist learning in Dewey, Piaget, and Montessori (ED533786). ERIC. International Journal of Instruction, 5(2), 195-212. https://files.eric.ed.gov/fulltext/ED533786.pdf

van Hout-Wolters, B., Simons, R.-J., \& Volet, S. (2000). Active learning: Self-directed learning and independent work. In R. J. Simons, J. van der Linden, \& T. Duffy (Eds.) New learning (pp. 21-36). Springer.

Vygotsky, L. S. (1980). Mind in society: The development of higher psychological processes. Harvard University Press

Walkington, C., \& Bernacki, M. L. (2020). Appraising research on personalized learning: Definitions, theoretical alignment, advancements, and future directions. Journal of Research on Technology in Education, 52(3), 235-252. https://doi.org/10.1080/15391523.2020.1747757

Watson, S. L., \& Reigeluth, C. M. (2008). The learnercentered paradigm of education. Educational Technology, 48(5), 42-48. www.jstor.org/stable/44429608

Watson, W. R., \& Watson, S. L. (2016). Principles for personalized instruction. In C. M. Reigeluth, B. J. Beatty, \& R. D. Myers (Eds.), Instructional-design theories and models, Vol. IV (pp. 109-136). Routledge.

Williams, N., \& Keith, R. (2000). Democracy and Montessori education. Peace Review, 12(2), 217-222. https://doi.org/10.1080/10402650050057861 